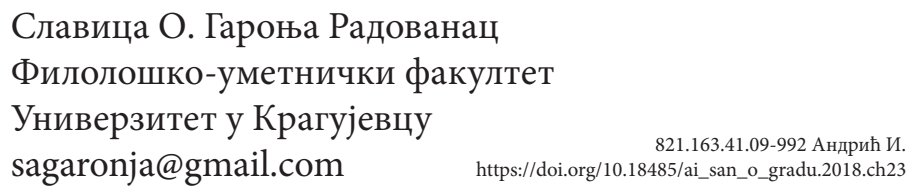

\title{
ПУТОПИСНЕ ОПСЕРВАЦИЈЕ О ГРАДОВИМА НА БАЛКАНУ У ДЕЛУ ИВЕ АНДРИЋА
}

Иако је много путовао и током своје дипломатске службе доста година боравио у различитим градовима Европе, познато је да Андрић није писао путописе у класичном (жанровском) смислу те речи. Међутим, простор као феномен имао је изузетну улогу у његовом целокупном делу. Отуд ћемо се задржати на градовима, који су по некој дубљој опсервацији, имали једно повлашћено место у Андрићевом делу. То су градови на Балкану, који је он најбоље познавао, проницао у њихову мистику и метафизику - истовремене лепоте и зла, са свом мешавином расних, религијских, језичких и културних утицаја у њима. У тим жанровски хибридним текстовима (између есеја и путописних опсервација) посебна пажња је посвећена градовима: Дубровнику, Почитељу, Охриду, Сарајеву и Вишеграду.

Кључне речи: Андрић, путопис, међужанровско прожимање, градови, Балкан.

Међу бројним компилацијским збиркама приповедака Иве Андрића, недавно се у издању Задужбине Иве Андрића, појавила и књига приповедака под тематским називом $\Gamma$ pagoви. ${ }^{1}$ Летимичан поглед на ову књигу,

1 Иво Андрић, Граgови, Задужбина Иве Андрића-Лагуна, Београд, 2016. 
иницирао је размишљање о статусу града у Андрићевом делу, па посредно осмислио и ову тему. Наиме, као што је познато, простор као феномен имао је изузетну улогу у Андрићевом делу и суштински га одредио: било као фикцијско место радње (Вишеград и Травник), као лирска реминисценција (градови на мору, реци), најзад и као опсежна, андрићевска мудра опсервација, која из простора и времена (Босна, Београд), контемплира много више и дубље, него што се то из класичног путописа као жанра може спознати. Треба напоменути, такође, да је Андрић током своје дипломатске службе, али и приватно, био изузетно покретљив и велики путник, са дужим периодима боравка у појединим градовима Европе. Међутим, о њима није остављао обимне путописе на начин како су то, рецимо, чинили Милош Црњански² или Јован Дучић³.

У споменутом избору приповедака (Андрић : Граgови 2016), где дакле, жанр финкције доминира, места радње су оквири за људску судбину, а наслови тек просторне ореднице за њу („Дан у Риму“, „Ноћ у Алхамбри“ - реч је о лотос-бару у Букурешту, Трст у „Заносима и страдању Томе Галуса“ и сл.). На тај начин формиран је и циклус „београдских прича“ где је Андрић место радње и судбине својих јунака сместио и у овај град свог највећег дела живота, што је већ, као тематска књига, такође реализовано. ${ }^{4}$ У том смислу, предмет овог рада биће текстови нашег нобеловца,

2 Милош Црњански, Пуйоӣuси (Сабрана дела, књ. ), Задужбина Милоша Црњанског, Београд, 19. Видети и студију Слађане Јаћимовић Пуйойисна ирроза Милоша Црғанской, Учитељски факултет, Београд, 2009.

3 Јован Дучић, Граgови и химере, Соларис, Нови Сад, 1996.

4 Ivo Andrić, Beogradske priče, Zadužbina Ive Andrića - Laguna, Beograd, 2011. 
разасути у књигама разнородних текстова у његовим Сабраним делима (1976), што имплицира тезу да се Андрић путописом као жанром никада није наменски бавио, већ више узгред и „успут“, мада је већ прецизно утврђено када је почео да пише и путопис. ${ }^{5}$ Али, његово проницљиво око и дубока мисао су реаговали на бројне „стазе, лица, пределе“, или својеврсне „знакове“, како би се нарочито могао назвати један специфичан андрићевски жанр опсервирања живота и света који га је окруживао. У том смислу, своје место су нашли они путописи, писани као осврти, кроки записи, чак и „извештаји“, али и читави развијени путописни есеји, поводом којих је његов уметнички и осетљиви дух имао потребу да остави свој траг, дакле често хибридни жанр различитих уметничких утисака, сензација и домета.

Такође, Андрићеве путописне опсервације можемо поделити на утиске са путовања у иностранство, као и утиске поводом виђења наших предела, и нарочито - градова. Такође, сви ти текстови се често стилски разликују, по намени писања или унутрашњој кохеренцији, па их можемо поделити на оне писане пре Другог светског рата и настале касније. У првима провејава млади Андрић, који још опробава своју мисао и перо, у другима зрели Андрић, већ великог имена, да би у трећим - и најуспелијим - који ће бити предмет овог рада, он био онај зрели Андрић, пронашавши и развијајући своју препознатљиву поетику (о градовима), још од двадесетих година 20. века, а касније само допунивши тај дискурс на нивоу својих највећих дела (романа и приповедака). Довољно је напоменути да је

5 Žaneta Đukić Perišić, Pisac i priča: stvaralačka biografija Ive Andrića, Akademska knjiga, Novi Sad, 2012 (Poglavlje: Putopis, str. 266-267). 
Андрић у путописној форми иза себе оставио краће или дуже текстове посвећене следећим земљама и градовима Европе, које је посетио пре или непосредно након Другог светског рата: Пољској, Аустрији, Португалу, Шпанији, Турској, СССР-у, а од тога градовима: Кракову (Писма из Кракова, 13-29), Бечу, Риму, Лењинграду (Петрограду), Стаљинграду (Волгограду). ${ }^{6}$ Као што се види, утисци су спорадични: из Кракова пише током студија, у Бечу је након изгубљеног Првог светског рата, описујући аустријску престоницу са свим елементима тешке послератне кризе. У Желазну Волу крај Варшаве, отишао је првенствено због Личности да посети родну кућу Шопена. И чини се да су свуда људи од већег интереса за писца, него искључиво сами предели: „Звезданог неба и људског лица никад се човек неће моћи нагледати“ (Андрић, „Лица“, 1976 : 173). Истовремено, свој путопис по Кини Андрић започиње такође класичном максимом: „Очима се дух не може наситити“ (Андрић, „Сусрет у Кини“ $1976: 179$ ).

Управо у овом путопису по Кини, Андрић се задржава на самом феномену путовања. Сазнање, одговор на неко важно филозофско питање и случај који то удеси на неком од тих путовања, Андрић сматра најблагороднијим резултатима свих померања човека из места сталне етзистенције. Он то назива „драгоценим тренутком великог духовног задовољства“ и каже:

„То је оно што у ствари и тражимо на нашим путовањима.

6 Реч је о следећим приповеткама: „Писма из Кракова“, „У Шопеновој родној кући“, „Кроз Аустрију, „Португал, зелена земља“, „Шпанска стварност и први кораци у њој“, „Први дан у радосном граду“, „Летећи над морем“, „На Невском проспекту“, „Утисци из Стаљинграда“. Сви се налазе обједињени у књизи „Стазе, лица, предели“ (Сабрана gела Иве Анgрића, књ. Х, Београд, 1976). 
Путописне опсервације о градовима на Балкану ...

Јер мени је одавно јасно да човек због таквих тренутака и путује по туђим земљама, и да, ломећи се светом, обијајући прагове музеја и загледајући лица људи и фасаде кућа, тражи у ствари само једно: оно што је, у бескрајној разноликости и привидној супротности облика, заједничко свих људима, свих времена и свих географских ширина.“ (Андрић 1976: 180)

Овакве филозофске опсервације дубље нарави, разасуте су кроз његове различите путописне текстове, које понекад Андрић скромно назива „забелешке с пута“, или „одломак путописа“, попут записа „Кроз Аустрију“, из којег вреди такође навести уводни део, као својеврсни прилог „филозофији путовања“:

„Кад људи имућни и жељни знања хоће да загледају у смисао цивилизације, њихова развоја и пропадања, они иду па гледају Форум или Помпеје или шетају по рушевинама Картаге на месечини. Тај је начин исто толико нетачан колико пријатан. Те су благородне рушевине, савесно поредане и прописане, избељене и испране, чисте као оне глатке кости на којима уче студенти медицине. Све што је тешко, горко, земно спало је с њим, и гледајући их ми видимо плодна столећа, прекрасан цват и благо отмено умирање, јер према једној мало грубој Хајнеовој речи - насликана ђубришта не заударају.“ (Андрић 1976: 187)

Колико у свом дубоко усредсређеном духу путопис сматра „успутним“ жанром, посредно наводи сам Андрић у истом путопису кроз Аустрију, где разгледајући бечке излоге износи: „Што пада у очи, то је несразмерна множина путописа и политичких брошура“ (193), да би насупрот томе, мало даље, изникао његов уметнички кредо, који се издиже из обичне путописне белешке, васпостављајући сопствени вредносни си- 
стем (у књижевности):

„Никад неће умрети лепота, а све кад би се то и догодило, преживела би је жеља за лепотом“, што се може сматрати његовом мисијом којој је вечито служио у свом делу (192).

1.

Управо из ове позиције појављују се, као кључни, неколики текстови о градовима, које обједињује заједнички именитељ - Балкан. У темпорално-културолошком смислу, то су градови Босне из доба Отоманске империје, као и један на самој граници са њим, на Медитерану (Дубровник), у којима се Андрић у најпунијем смислу, духовно-сензитивном, налази „на свом терену“, које осећа, воли и познаје дубље него било која друга места која је посетио, мада је у другима и живео и стварао (и о њима летимично писао). Градови у којима je, дакле, осетио пуну меру свог уметничког сензибилитета и потенцијала, јесу неколики градови Балкана, где је пишући о њима, Андрић на граници најбољих страница своје уметничке прозе и есејистике, односно, у најквалитативнијем смислу путописа као хибридног жанра. Ти „повлашћени градови“ о којима Андрић оставља најнадахнутије странице су: Дубровник, Почитељ, Сарајево, Вишеград и Охрид. Сем, на неки начин, програмског текста „Сан о Граду“ (посвећеног Дубровнику), сви су настали раних педесетих година, које и јесу зенит стваралачке зрелости већ оформљеног писца. Један карактеристичан и врло специфичан материјални квалитет обједињује ове градове на Балкану, а то је - камен. Фасцинација каменом (и сунцем), може се рећи, представља суштинску квалитативну одредницу одабраних тексто- 
ва о градовима Балкана, па и важну поетичку одредницу у путописно-есејистичкој прози Иве Андрића.

Интересантно, замајац овој фасцинацији градовима Балкана (нарочито отоманске Босне), Андрић поетички обједињује и имплицира у једном другом тексту („На вест да је Бруса погорела“)”, који ближе одређује генезу тог хронотопа, култролошког феномена, који је дакле, најбоље разумео, осећао и у њему највише као уметник дао. У споменутом тексту, издижући се изнад дневне и трагичне вести (нестанка старог града у пожару), Андрић исписује и пасусе који се издижу у сферу универзалних увида, и то, пре свега поетичких образаца за сам путопис као жанр:

„Има градова, па и великих и чувених градова, које разгледамо и напустимо без жаљења, и који се, оставши иза нас, распрше као облак прашине. А има других који остану у нама као дубок интиман доживљај о коме није лако ни ћутати ни говорити. Такав град је и Бруса.“ (Андрић 1976: 145)

Почињући од временске тачке, у којој је свет вековног трајања поништен и све што је некада чинило град нестало у једном трену, Андрић се из ове универзалне сфере усмерава на простор личног сећања на Брусу, коју је некада давно посетио и доживео дубље него многе друге градове, фокусирајући се на „искрсло једно једино сећање, и то сећање на један невидљив доживљај, сав личан и унутрашњи“. Управо овде, у маниру авангардног путописа ${ }^{8}$, размичући границе жанра, Андрић издваја тренутак стапања сопствене има-

7 Иво Андрић, „На вест да је Бруса погорела“, НИН, год. VIII, бр. $413 ; 29.11 .1958$.

8 Слађана Јаћимовић, Пуйойиси срӣске авані̄apge, СКЗ, Београд, 2005. 
гинације (бројних приповедака које је већ написао) са стварношћу виђеног:

„На крају тог узбудљивог града, уморан и пун утисака, стајао сам још дуго на тераси испред Зелене џамије и посматрао испод себе, као на некој макети, разастрту слику старе Брусе....Дуго сам остао тако сричући поруке које су вејале из те слике. Кад сам, најпосле, дигао занесен поглед пут осветљеног западног обзора, угледао сам пред унутарњим погледом, у муњевитом скраћењу, вековни процес великих османлијских освајања који су дуго полазили од ове тачке....Са тог места, у том тренутку, указала ми се можна и дуга линија продирања турске војне и државне силе и њиховог начина живота са којима су упоредо ишле и њихова архитектура и урбанистика. ....На тиој линији налазе се мноіи наши іраgови (моје подвл.)....не само Скопље и Сарајево него и тамо неки забачени Маглај или Почитељ, који су њен урбанистичко-архитектонски одраз, јачи или слабији, али верни одраз....

У светлости тога тренутног виђења, ја сам пратио многовековни пут те силе која је рушила и градила, напредовала и стагнирала и по нашим земљама..." (Андрић 1976: 147-148)

Уносећи „тренутке“, „магновење“, „унутрашњи и невидљив доживљај“ векова у панорами града, Андрић је недвосмислено проговорио и као песник, што је квалитет који краси његове најбоље, не само романе и приповетке, већ и путописе са овом врстом надахнућа („које у мени и данас сја и траје“), што је и рангу са неким најбољим записима Милоша Црњанског или Растка Петровића. И сам свестан квалитета „тренутка магновења“ у простору-времену, који успоставља као истински вредносни систем и једини смисао сваког правог путовања и доживљаја („То је био мој главни и најдубљи доживљај на целом том путовању“), Андрић у овом тексту поентира, 
и најављује то дубље, поетско искуство у путопису - ту магистралну линију коју ће развити у својим најбољим путописним есејима о нашим градовима на Балкану, насталим под утицајем доживљене вековне отоманске културе Брусе - и којима овај текст симболички представља неку врсту поетичког пролога, иако је хронолошки настао неку годину касније:

„Има градова које разгледамо и одемо из њих, а исто је као да их нисмо ни видели, има других које памтимо па полако заборавимо, али има и таквих са којима останемо трајно повезани на чудан и нераскидљив начин.“ (Андрић 1976: 147)

Ако покушамо да одредимо генезу тог процеса, идући хронологијом тог опуса - путописно најуспелијих Андрићевих есеја о градовима на Балканском полуострву у додиру са Медитераном - обједињених феноменом камена, који најбоље обједињује поетику времена и простора, кроз људски чин градње као суштинске цивилизацијске одреднице, онда такав домет Андрић постиже већ у свом програмском тексту - „Сан о граду“, посвећеном Дубровнику. ${ }^{9}$ Овај текст је вишеструко значајан, као нека врста увода у „зрелу фазу“ Иве Андрића, односно, апсолвирања огромне грађе прикупљене за докторску дисертацију о развоју духовног живота у Босне током отоманске владавине ${ }^{10}$,

9 Први пут овај текст је Андрић објавио под насловом: „Сан о граду“ - Поводом Ива Војновића, „Машкарате испод крупља“, Јуїословенска ғива, год. VII, knj. I, sv. 3; 1923.

10 Докторску дисертацију „Развој духовног живота у Босни под утицајем турске владавине“, Иво Андрић је одбранио у Грацу 1924. године. 
и као зачетак његове поетике, која ће изнедрити његове најзначајније приповетке настале између два светска рата, као и романе настале током Другог светског рата (На Дрини ћуйрија, Травничка хроника, Госиођица). Тим поетичким особеностима и стилом, исписане су и странице о Дубровнику, чију „тајну“ и суштину, Андрић уклапа у своју поетику ослањања на простор његове трајне фасцинације - херцеговачко залеђе и Босну.

„Замислите наш говор како се из Босне, преко Херцеговине, глади и мекша, док не стигне у Жупу дубровачку, где га сељакиње говоре с лепотом и достојанством краљица...

Замислите, даље, наше 'Словине' како на помолу мора бацају мешине и остављају чобанима овце, а они се уљуђују, уче, тргују и стичу, а стечено богатство прерађују, промећу нараштајима из руке у руку, док не изгуби оштрину и задах зноја и цењкања и сјај новине и све се не претвори у друштвену складност, у уметност, у сјај, у стваралачку мисао. Примивши веру и цивилизацију тога времена они - граде." (Андрић 1976: 98 $)^{11}$

У овом врло промишљеном, а песнички надахнутом прологу, Андрић открива „чудо града“ и тајну трајне фасцинације (историјске, дипломатске) и славе града Дубровника, тог свакако, најзахвалнијег примера колико је словенска раса била кадра да створи и куда би стигла, да су јој на просторима Балкана то историјске прилике дозвољавале: „Ту између глува крша и безумна мора, они су обележили своје место, у најлепшој људској жељи да се кратки живот радом и смислом сублимира и овековечи“ (Андрић 1975: 99). Фасцинација

11 Сви цитати су према: Иво Андрић, Сйазе, лииа, ӣреgели, Сабрана gела Иве Анgрића, књ. 10, Београд, 1976. 
градњом, као најплеменитијим људским чином, савладавање нереда лепотом, лежи у сржи већ тада спознатог, властитог поетског креда, кога ће се од тада Андрић чврсто држати, а најраскошније развити и транспоновати у романескној форми, кроз мотив моста у роману На Дрини ћуйрија.

Након овог есејистичког пролога, у тексту „Сан о граду“, појављује се прави путописни текст, односно, кроз наглашено лични доживљај (приповедачко - ја), путопис са јаком фикционализацијом, који, сем што повремено има облик наративне структуре приповетке, одликује и наглашени поетски дискурс, на шта сугерише и сам наслов („Сан о граду“): „Ово је хисторија Града. Такву сам је сагледао и осетио једног пролетњег дана до подне“ (Андрић 1976: 99).

Централни лични (и поетски) доживља Града представљен је наративно: сасвим обичним успоном „на Горњи Канал“, у коме се појављују све сами стварносни елементи приповедања (сунчање „у заветрини неке капелице“, наилазак на „стара врата са зарђалим гвожђем“, додир по њима и звонце, а након њега и „један чичица“, што овом тексту даје облик приповетке типа прозе Растка Петровића (љуgи іоворе). Но, након овог пролога, изниче истински и поетско-ванвремени призор Града, након чега престаје прича и настаје чист путописни есеј: „....јер се преда мном указа Дубровник онакав какав треба да се види да би га се разумело. Све је одатле у правој мери и пуној величини. Куле, терасе, куполе, дворишта, вртови и море“ (Андрић 1976: 100). Мудре реминисценције типично андрићевског типа, и овде богате путописни жанр. Јер, како сам писац наводи: „Никад не бих помислио да се на један корак из оне криве, стрме и као гроб тесне улице отвара такав видик. Заистиа нас случај најбоље воgи (мој курзив, Ан- 
дрић 1976: 100). Апстрахујући наративне пасаже који и даље прате ову радњу (монолог старца који одржава запуштено имање, реалистички прецизан и истовремено песнички опис свих детаља напуштене властелинске виле и њеног дворишта), а све то заправо само декор за поетску занесеност призором пред собом, писац се на тренутак одваја од стварности да би исказао суштину дубљег, онотолошког доживљаја града:

„Одатле, из тог каменог белог дворишта сам први пут видео Дубровник онакав какав је био и морао бити. Ту ми је, бар мало и бар на час, била видна: вјера, господство и слобода / Дубровника, мирна града... Одатле ми се први и последњи пут приказа Дубровник широк и велик....“ (Андрић 1976: 101)

Управо од овог пасуса, настају пасажи који демонстрирају Андрићеву поетику највишег кова, насталу већ тада, а потом широко развијану у свим његовим делима. То су увиди универзалних вредности, настали на основу промишљања, као и поетског доживљаја једне конкретне појаве, у овом случају, града као дела људских руку, људске жеље за лепотом и хармонијом у хаосу, а све то повезано са митским законитостима жртвовања, да би се нешто трајно саградило и да би оно у времену и простору опстало (чему се Андрић ближи такође митском поимању настанка града у нашим лирским народним песмама и баладама, попут „Зидања Скадра“"12, а највише развијеном у потоњим делима, превасходно у роману На Дрини ћуирија) $)^{13}$.

12 Вук Стефановић Караџић, Срӣске нароgне ӣјесме, књ. II, бр. 25 (Нолит, Београд, 1977).

Миодраг Павловић, „Тумачење трију митолошких народних песама“, Анйолоіија тирске нарояне йоезије, Београд, 1989 (203-204).

13 Видети студију Петра Џаџића, Храсӣова іреgа у каменој ка- 
„Како је чудно и увек благотворно осећање што га имам кад гледам клесан камен, рађену земљу и тесано дрво. Видим да је лепота и целисходност сваког облика искуйлена жрйвом (мој курзив): рада и подвргавања законима. Зато је све што је створено у прошлости живо и непромењиво у садашњости, јер је откупљено и плаћено, а дужина века му се мери йо величини жрйве којом је ойкуйльено." (мој курзив, Андрић 1976: 101)

Управо, у опсервацији Дубровника, у једном фиксираном тренутку дубљих спознаја, у наставку овог текста и некој врсти разраде ове своје поетике, Андрић долази до суштинских увида, који ће бити транспоновани у његовим делима у целини, поглавито кроз феномен градње „свих лепих и корисних грађевина“, међу којима, уз градове, у његовом делу доминирају и мостови:

„Мудри дубровачки зидови, видим да је рад једино што човек може да супротстави свом непознатом удесу. ...Они су божанско у нама и зато све води и усавршују, све предвиђају, рођење, рад, љубав, смрт, и сам преступ закона, и њега казном и патњом своде опет у меру и изједначују тезуље, да се милост и осмех сами враћају.“ (Андрић 1976: 102)

Такође, у онтолошком смислу, допуњујући ову спознају, Андрић се винуо свакако у најзначајнију опсервацију целокупног овог текста, али и сопствене поетике у настајању:

„Почетак и услов сваког делања је оіраничене (мој курзив). Зато ниједна граница није оков, како се нама често чини, него прва црта вишег промисла, ӣочетиак сйварања. (мој курзив, Андрић 1976: 102)

йији: митиско у gелу Иве Анярића, Београд, 1993. 
И сам свестан једног изузетног тренутка проникнућа у поимање града као таквог, али и емитовању сопствених вредности (где се поклонио „вјери, господству и слободи“), срећно га насловивши као „Сан о Граду“, Андрић своју путописну реминисценцију (забележену у Трсту, без датума), закључује реченицом: „Као у сну сам се опростио са старцем и сишао у град“" (Андрић 1976: 102).

2.

Поетичко доврхуњивање овог круга Андрићевих текстова о балканским градовима представљају путописи о Почитељу у Херцеговини и Охриду у Македонији. Оба текста су настала у пуној зрелости Андрићевог стваралаштва (педесетих година 20. века) ${ }^{14}$, као већ афирмисаног и цењеног писца, а који стилским својствима и квалитативно само проширује и продубљује већ започет уметнички процес опсервирања градова на Балкану, започетих пре двадесетак година, есејистичким путописом о Дубровнику.

Нема сумње, Почитељ припада самој сржи Андрићеве фасцинације временско-просторном парадигмом Балкана и његове дуговековне (отоманске) културе. У тексту „На камену, у Почитељу“, такође су присутне већ дубоко формиране поетичке карактеристике његове дубоке, мудре мисли, као и карактеристичног стила: започињући сликовитом метафором и антропоморфним описом („Почитељ. На једној нози стоји, једним се стопалом држи земље, и то не целим. Није лак ни удобан положај.“), писац у тзв. „безличном

14 Иво Андрић, „На камену, у Почитељу“, Књижевне новине, год. I, br. 3, 28. I 1954.; Иво Андрић: „Крај светлог Охридског језера“, Борба, Београд, год. ХХ, br. 284, 29-30. XI 1955. 
дискурсу“ („За шест векова бити град од камена, у стрмој, кршевитој и тесној долини Неретве, на тешком и изложеном месту „земљи на ћенару“, није лака ствар ни завидна судбина“), прелази у фикционализацију из које се врло лако могла развити и раскошна приповетка. Те могућности писац није (намерно!?) искористио, мада је све могло да „склизне“ у њу:

„Било је, и морало је бити, много чамотиње и досаде и аскерског чмавања у очекивању сукоба и опасности које не наступају, док живот постаје сав једно једино једнолично ишчекивање без краја, а са заборављеним првобитном сврхом. Било је чежње за покретом и ширином, уживањем и променом, оштре и болне као сечиво у живом месу. Али било је, и морало је бити, и радости, дивље, кратке и војничке, у сваком беласању женске кошуље на чобаницама са друге обале, у ћилибарски жутом мостарском вину које љуљушка у себи неухватљив и сталан зеленкаст одсев и које је, поред сласти и опоја, имало за исламског ратника и драж забрањеног и грешног уживања. Било је сласти у воћу из присоја, у топлој погачи и неопходној кафи, у јаком љубушком дувану, добром и нераздвојном другу дневних и ноћних часова.... Било је и морало је бити.“ (Андрић 1976: 255)

Уместо приповетке, у другом одељку, проговара путописац, и то у првом лицу једнине:

„Од тог обореног топлог камена са бивших грађевина, под сунцем које је исто, у мене је увек улазила узбудљива визија живота помрлих људи и нараштаја, њихових потреба, страсти, веровања и заблуда, судара, привлачења и одбијања, вечитог таласања људског мора на тврдој и непролазној земљи.“ (Андрић 1976: 257) 
Сем читаве једне приче о смокви (Андрић 1976: 257-258), фокус путописне фасцинације Почитељем налази се у трећем одељку, који такође има обрисе приповетке, типа Љygu iоворе (Р. Петровића), јер се у непосредан опис предела уводи и људски однос, односно, једна људска ситуација. („Још овде живе људи. Малобројни и навикли на живот у бившем граду. (мој курзив). Још куће носе бројеве. Али се може догодити да отворите неколико таквих врата са бројем, све једна за другим, а да уместо живих људи и стварне куће угледате чкаљ и траву зарасло двориште и костур од некадашње куће, са прозорима из којих зјапи празнина. А може вам се десити да на звук каната који се отвара одједном чујете из оронуле куће женски глас, слаб и старачки: - Ко је то?“ (Андрић $1976: 258)$ )

Управо на овом месту јавља се Андрићев универзални контекст, вечито будног духа заокупљеног нашим поднебљем и људима, који вековима живе на њему („У том гласу живи старина нашег језика, са бојама и дужинама самогласника, какве се више нигде по савременим насељима не изговарају и не чују“ (Андрић 1976 : 259)). Попут сагледавања Дубровника са видиковца, и Почитељ писац спознаје једном типичном сценом: самоћом и седањем на „врео оборен камен, на највишој тачки града“. У тој фасцинацији сунчевом светлошћу и видиком пред собом, Андрић васпоставља своју поетику: од песничког надахнућа и визије слободе и лепоте, лепше него што је све у стварности, слика се мења, и живот се враћа у своју прозу:

„Не зове се никако, не означава ничим и не бележи нигде оно што казује овај тренутак на камењу, међу камењем, под зенитским сунцем. Дан нема имена, 
Путописне опсервације о градовима на Балкану ...

време нема мере, свет је изгубио границе. У савршеној равнотежи мирују тасови постојања и непостојања.“ (Андрић 1976: 259-260)

Истовремено, са заласком сунца, призор (а тиме и филозофска димензија) из основа се мењају:

„Али, већ идућег трена сказаљке ће се помаћи из свог подневног положаја... - и све ће се указати нашим очима онакав какав је, све ће се звати по имену и мерити устаљеним, ограниченим, нама приступачним мерама наше мисли и нашег корака. Све ће постати оно што је... Кренућемо са поворком. За нама ће остати неизречен, неизрецив и мимо сваку меру велики тренутак безимене величине и варљиве, дивне равнотеже света.“ (Андрић 1976: 260)

Цео овај „наук“ изнедрио је медитативан тренутак у Почитељу. И стога, као поетско-филозофски кредо, може послужити и завршни пасус овог путописног eceja:

„Заборавићемо наук и поруку камена у рушевинама, и ништа на свету неће моћи да нам их потпуно оживи у сећању. Ништа. Ни ови редови које бележим на том камену, у подневни час.“ (Андрић 1976: 260)

Путопис „Крај светлог Охридског језера“, почиње in medias res - такође, ухваћеним тренутком извлачења рибарских мрежа и довикивања рибара тим поводом - из чега Андрић извлачи дубљу филозофску премису: „Заиста завидна судбина: постојати само као неопходан и непогрешан сигнал, кратак а речит, у великом животном оркестру људских речи и гласова једног краја. Бити једино то и као такав, по извршеном задат- 
ку, нестати“ (Андрић 1976: 262). Међутим, већ следећи пасаж има све реалне конотације личног, субјективног доживљаја (купање на Охридском језеру), са песничким препуштањем сензацијама светлости сунца, које назива „крупном звездом“, и једном веома важном, типично андрићевском максимом: „Све то траје кратко, као свака лепота, а понавља се безброј пута“ (Андрић 1976: 262).

Сем сензације светлости, воде и камена, у овом путопису, приликом посете делу људских руку - цркви Свете Софије, Андрић уноси још један чулни елемент из те „хармоније сфера“: звук, тачније музику. Уз људске гласове (мајстори који скидају малтер са фресака, којим су их Турци премазали), који постају иреални, jep их посетилац не види, фасцинацију допуњавају одјеци у самој цркви, кроз које он види и чулно осећа све слојеве минулих епоха и нараштаја:

„Сводови отпевају. Мелодије се укрштају, али се не мешају и не потиру међу собом, него, праћене лавиринтском јеком, стварају звучни слив у коме неколико мелодија, на свом увиру у море тишине, тече као неколико још засебних река већ повезаних близином заједничког ушћа. У јеци сводова нејасно се јављају и брзо тону ноте одрицања и заноса минулих веровања, испреплетене и помешане с песмом овоземаљске жеље и љубави, с прегнућима и надама наших дана. А испод њих, чини ми се, наслућујем нејасне обредне тонове паганских храмова чији су мраморови заробљени дубоко у зидовима овог светилишта, које је служило толиким епохама и нараштајима.“ (Андрић 1976: 263)

И сам град Охрид, доживљен такође са висине Самуиловог града, „под сунчевом светлошћу“, у знаку је „звука и мелодија“. Наиме, проналазећи контраст у 
овом „пределу тишине“, Андрић закључује да овде „по вечитом закону супротности, живе бујним животом звук и мелодија... Овде мелодије старе и нестају, али не умиру; не рађају се, него васкрсавају“ (Андрић 1976 : 265). Пењући се стрмим улицама старог града, Андрић васпоставља и једну својеврсну менталитетску филозофију градитељства (охридских кућа и улица).

„Пењем се између кућа које су као сестре у породици богатој децом, све сличне а ниједна потпуно иста. Све је стрменитији и напорнији пут, али видик неће да се отвори. Изгледа као да је смисао ове урбанистике у овом: улица је само за то да би њоме дошло кући, а о човеку који куће нема и који се задржава на улици, и не треба водити рачуна. Улица је напор и једноличност, а кућа је одмор и уживање. (мој курзив). Тек кад уђете у кућу и кад се испнете на спрат, ви можете са доксата или с високог прозора да видите оно што је, како изгледа, главни циљ ове архитектуре, и што даје све што људима треба: ваздух и сунце и лепоту видика на језеро и пределе око њега." (Андрић 1976: 266)

Управо, и на овом месту, доминира, готово као лајт-мотив, најинтензивнији доживљај једног града у Андрићевим путописним есејима, а то је: видик надалеко и лепота изазвана њим, као симбол слободног и неспутаног људског и песничког духа. У путопису по Охриду, Андрић тај доживљај потенцира:

„Пењем се немилосрдном калдрмом, између затворених капија и белих зидова...Да ли ово уопште има краја и излаза?

Док најпосле, одједном, сав прозрачан и светао, не пукне видик пред чијом се лепотом занеми. И то је најбоље. Не рећи нишйа, ни у себи (мој курзив). 
Свако дивљење треба оставити за мање, и мање необичне лепоте....Стојим и гледам, и само ми је тешко да помислим да ће се морати сићи одавде, спустити се." (Андрић $1976: 266$ )

Из овог се развија специфична унутрашња законитост његовог опсервирања охридских кућа, а на неки начин и менталитета људи, осетљивих на лепоту, коју претпостављају материјалности живота (и условима живота):

„...Али сад кад видим какав је јединствен видик разапет пред сваким прозором сваке од ових трошних грађевина, ја почињем бар донекле да разумевам фантастичан алфабет ових издужених кућа и необично истурених доксата....Очигледна је овде потреба и жеља да се на сваки начин и по сваку цену има свој gео свейлосӣи и вазgуха и свој йоїлеg са висока. (мој курзив)....А на махове, те куће изгледају као да су се судариле у свом брзању збрдо и својој јагми за што боље место и што шири видик....(Андрић 1976: 267)

И на врху видика и погледа на Охрид, Андрић постиже јединствене контемплативне увиде, које заокружује у складу са променом дневне светлости:

„Тек сумрак ми је онемогућио даље читање те бескрајне приче и присилио ме да се вратим.“

Кроз овај начин опсервирања, Андрић уобличава у трајну вредносну категорију и јединствен менталитет балканског човека (Македонаца око Охридског језера), стечен из утиска како је човек саображен са послом који ради:

„Не треба много па да се сагледа једна од карактерних црта овдашњег човека. То је његова велика сабраност и способност да се усредсреди и потпуно преда 
послу који ради....Ретко се где у нашој земљи може видети човек тако срастао и сливен са послом који ради, као на обалама овог језера.“ (Андрић 1976: 265)

3.

Најзад, и о једном од кључних градова свог сазревања, Сарајеву, центру простора којем је посветио готово сав свој књижевни опус (Босни), Андрић је написао више текстова. За ову прилику, у форми путописне есејистике, пажњу ћемо обратити на посебно индикативан и на неки начин, програмски текст: „Један поглед на Сарајево“. 15

У овом путописном есеју видна је изразита ритмичност његове песничке имагинације, која овом тексту даје нешто од песме у прози: сем ритмичког понављања исказа на почетку сваког одељка поглавља („То је град“), овде је присутно опсервирање простора (кроз време) иницирано, такође, погледом са град са видиковца, као омиљене Андрићеве перспективе доживљавања градова који су га на неки начин (и управо из те позиције) опчинили. Тако ове особености можемо сматрати такође, поетичким константама, које је он уобличавао и непрестано ширио и богатио на примерима одабраних балканских градова о којима је писао, који су га трајно фасцинирале и којима је посвећивао своје контемплативно-поетске странице.

У тексту „едан поглед на Сарајево“, Андрић наговештавајући позицију посматрања града прониче у саму морфолошко-језичку суштину појма „град“ („Почевши од оног фантастичног смисла који та реч има у бајкама што смо их слушали као деца...“ „Па онда их доведоше у један в-е-лики гр-а-а-ад....“), након чега

15 Иво Андрић, „Један поглед на Сарајево“, Југославија, св. 7, 1953. 
своју пажњу усмерава на поједине његове феномене, издељене на три одељка. У првом, то је песнички опис града „са висине“ са „својим баштама и улицама које су исписане и нацртане на падинама стрмих брегова као на страницама напола отворене књиге“ (Андрић 1976: 117), да би се то преточило у историјску причу о граду. У другом одељку, такође поетски интонираним истим исказом („То је град“), Андрић даје једну врсту географског „описа“" града, којем повремено даје антропоморфно лице: „Тако Сарајево има два вида и два лица, једно тамно и строго, а друго светло и љупко“ (Андрић 1976: 121), које он и образлаже:

„Те два историјске условљене и противречне особине града оставиле су трага и у души сарајевског човека: самосвест, предузимљивост, жељу за пунијим животом и даљим видиком, а преко свега тога вео меланхолије, дах неодређене тескобе и историјског опреза према животу и свему што живот доноси. “ (Андрић 1976: 122)

Трећи и најпоетичнији одељак, представља и Андрићеву ослобођену имагинацију, инспирисану видиком, са кога чудесном интуицијом он не само да слика онтологију Града, већ продире и у дубљу метафизику његове историјске судбине:

„То је град. Тај утисак и та помисао намећу се увек кад се испнемо на један од висова који, окружени старинским утврђењима, стешњавају и надвисују Сарајево....Под нама у љубичастом сумраку тоне све више старо Сарајево, са својим грађевинама свих времена и стилова, својим црквама, старим и новим, синагогама и многобројним џамијама поред којих расту јабланови, витки и високи као минарети. Град буна и ратова, новца и гладних година, кужних епидемија и разорних пожара, град вештих људи који су 
увек волели живот, иако су га познавали и с лица и с наличја. Његово лице у последњој светлости сутона изгледа древно мудро....“ (Андрић 1976: 122-124)

У овом хибридном тексту о Сарајеву, који почиње неком врстом историјског извештаја и географског описа са примесама савременог времена, а завршава се песничком апотеозом, изниче својеврсна Андрићева поетика градова као фасцинације највишег културолошког феномена људског станишта и човекове егзистенције у њему. Сарајево на овај начин, у мудрим андрићевским сликама, опстаје као парадигма града, са својом метафизичком судбином, коју је и Андрић овим текстом фиксирао у универзалној равни:

„I u koje god doba dana i sa kojeg god uzvišenja bacite pogled na Sarajevo, vi uvek i nehotice pomislite isto. To je grad (moj kurziv). Grad koji i dotrajava i umire, i u isto vreme se rađa i preobražava.“ (Andrić 1976: 125)

Последњи у овој анализи, а први у опусу Иве Андрића, кроз прослављени роман На Дрини ћуйрија, свакако је и Вишеград. Поетски текст „Стазе“, у целини је посвећен и инспирисан Вишеградом, као местом свих пишчевих почетака, градећи такође једну симболичну, вишезначну и универзалну раван на аутобиографској основи. ${ }^{16}$ Настао, такорећи, као пролог његовим великим романима, у предвечерје Другог светског рата, та „вишеградска стаза“ више је есеј него путопис, где је Вишеград фиксиран као пишчев genius loci, а путовање модернистички дато као (аутобиографско, спознајно)

16 Иво Андрић, „Стазе“, Српски књижевни гласник, н.с. књ. LXI, бр. $3 ; 1940$. 
животно кретање високе симболике, садржавајући нешто од суштинске поетике целокупног Андрићевог опуса. Оно представља и једну врсту имагинарног путовања кроз себе, откривајући генетску везу: одакле је велики писац кренуо на свој тегобан, али и надасве успешан животни и уметнички пут, а кроз прве спознаје стечене управо у овом граду и „на његовој стази“:

„На почетку свих стаза и путева, у основи саме мисли о њима, стоји оштро и неизбрисиво урезана стаза којом сам први пут слободно проходао.... На тим стазама које ветар мете и киша пере а сунце окружује и раскужује, на којима се срета само измучена стока и људи ћутљиви, тврда лица, ту сам ја засновао своју мисао о богатству и лепоти света.....” (Андрић 1976: 9-10)

Развијајући ову идеју у високосимболичну поетску метафору, Андрић од Вишеграда и његове тешке и тврде историје гради своје једино „златно доба“, своју „попутбину“ - уметничку валоризацију у којој има смисла градити и стварати ред, лепоту и смисао, у хаосу, бесмислу и злу, што ће се у његовој уметности изглачати кроз ванвремени симбол каменог моста у Вишеграду:

„И на свима друмовима и путевима којима сам доцније у животу прошао, живео сам само од те убоге среће, од своје вишеградске мисли о богатству и лепоти створеног света. Јер, испод свих друмова земље стално је текла само за мене видљива и осетна оштра вишеіраgска сйаза (мој курзив), од дана кад сам је напустио па до данас. У ствари, по њој сам ја одмеравао свој корак и подешавао ход. Целог века ме није напуштала...." (Андрић 1976: 10)

Из ове перспективе имагинарног путовања „по 
себи“, Андрић од тачке свог почетка - Вишеграда - испреда, заправо, своју јединствену уметничку аутобиографију, уточиште, и уметнички credo:

„У тренуцима кад ме замарао и тровао свет у ком сам по злу случају живео и чудом се одржавао у животу, кад се мрачио видик и колебао правац, ја сам тада побожно простирао преда се, као верник молитвени ћилим, тврду, убогу, узвишену вишеградску стазу, која лечи сваки бол и потире свако страдање..." (Андрић 1976: 10)

Тако, вишеградска стаза постаје његова животна путања: „...jа сам прелазио по један део тога пута са којег никад није требало ни силазити. И тако ћу до краја живота, невиђено и потајно, ипак прећи суђену дужину вишеградске стазе...." (10). Стапање људског живота са стазом-водиљом, у завршном пасусу, представља и Андрићев најдубљи увид у крај и коначност људског бића, али бића које оставља траг, поруку и завет, чиме се и овај путописно-филозофски есеј уздиже у саме врхове његове уметности:

„И изгубиће се тамо где завршавају све стазе, где нестаје путева и беспућа, где нема више хода ни напора, где ће се сви земаљски друмови смрсити у бесмислено клупко и сагорети, као искра спасења, у нашим очима које се и саме гасе, јер су нас довеле до циља и истине.“ (Андрић 1976: 11)

Закључак

У својим путописним есејима о градовима Балкана, Иво Андрић васпоставља посебан квалитет путописне опсервације, достижући на тај начин саме врхове своје књижевне уметности. Видно је да је Андрић у анализираним текстовима о балканским градовима и оних 
на граници са Медитераном (Дубровник, Почитељ, Oxрид, Сарајево, Вишеград), развио у целини своју поетику, која се препознаје у песничким константама (камен, светлост, лепота, трајност, ред), а која ће највише доћи до изражаја управо у његовом роману На Дрини ћyuрија. Другим речима, кроз ову анализу - од најранијег текста о Дубровнику (из 1923), до новијих, настајалих педесетих година 20. века, видна је та линија развоја особене поетике: дубоке контемплације, песничке фасцинације и филозофског, универзалног смисла, који и кроз примере у овој анализи, могу да се примене на читав Андрићеву поетику и књижевни опус.

\section{Разматрани текстови}

Андрић, Иво. „Сан о граду“ - Поводом Ива Војновића, „Машкарате испод крупља“. Јуіословенска ғива, год. VII, knj. I, sv. 3; 1923.

Андрић, Иво. „Стазе“. Срйски кюижевни іласник, н.с. књ. LXI, br. $3 ; 1940$.

Андрић, Иво. „Један поглед на Сарајево“, Јуїославија, св. 7, 1953.

Андрић, Иво. „На камену, у Почитељу“. Кюижевне новине, год. I, br. 3, 28. I 1954.;

Андрић, Иво. „Крај светлог Охридског језера“. Бор $\delta a$, Београд, год. ХХ, br. 284, 29-30. XI 1955.

Андрић, Иво. „На вест да је Бруса погорела“. НИН, год. VIII, бр. 413; 29.11.1958.

\section{Литература}

Андрић, Иво. Сйазе, лица, йреgели. Сабрана gела Иве Анgрићa, књ. Х. Београд, 1976.

Андрић, Иво. Знакови. Сабрана gела Иве Анgрића, књ. VIII. 
Путописне опсервације о градовима на Балкану ...

Београд, 1976.

Andrić, Ivo. Beogradske priče. Beograd: Zadužbina Ive Andrića, Laguna, 2011.

Andrić, Ivo. Gradovi. Beograd: Zadužbina Ive Andrića, Laguna, 2016.

Дучић, Јован. Граgови и химере. Нови Сад: Соларис, 1996.

Đukić Perišić, Žaneta. Pisac i priča: stvaralačka biografija Ive Andrića. Novi Sad: Akademska knjiga, 2012.

Јаћимовић, Слађана. Пуйойиси срӣске авані̄apge. Београд: CК3, 2005.

Јаћимовић, Слађана. Пуйойисна ӣроза Милоша Црюанскої. Београд: Учитељски факултет, 2009.

Караџић, Вук Стефановић. Срӣске нарояне йјесме, кю. II, $\delta$. 25. Београд: Нолит, 1977.

Павловић, Миодраг. „Тумачење трију митолошких народних песама“. Анйолойчја тирске нарояне ӣоезије, Београд, 1989 (203-204).

Џаџић, Петар. Храстиова іреgа у каменој кайији: мийско у gелу Иве Андрића. Београд, 1993.

Црњански, Милош. Пуйойиси I-II (Сабрана дела, књ. VIII і

IX). Београд: Задужбина Милоша Црњанског, 1995.

Slavica O. Garonja Radovanac

\section{TRAVELS OBSERVATIONS ABOUT CITIES ON THE BALKAN IN THE WORKS OF IVO ANDRIĆ}

\section{Summary}

Although he travelled a lot and worked for many years during his diplomatic career in various European cities, it is known that Andrić did not write travelogue in the classic (genre) sense of the word. However, space as a phenomenon had a very important role in his entire work: as a fiction place of action, as a lyrical reminiscence, and finally, as extensive, in the Andrić way, a wise observation, which from space 
and time, is much more and deeper than that It can get this from a classic travelogue as a genre. That is why we will keep in towns and places, which, after some deeper observation, had a privileged place in Andrićs work. These are cities in the Balkans, which he best known, break through into their mysticism and metaphysics - simultaneous beauty and evil, with its mix of racial, religious, linguistic and cultural influences in them. In these genre hybrid texts (between essays and traveler's observations, special attention is given to the following cities: Sarajevo, Višegrad, Počitelj, Ohrid and Dubrovnik.

Key words: Andrić, travelogue, inter genre permeation, cities, the Balkans. 